\title{
Pedagogies of Engagement: Classroom-Based Practices
}

KARL A. SMITH

Department of Civil Engineering

University of Minnesota

SHERI D. SHEPPARD

Department of Mechanical Engineering

Stanford University

DAVID W. JOHNSON

Department of Educational Psychology

ROGER T. JOHNSON

Department of Curriculum and Instruction

University of Minnesota

\section{AbSTRACT}

Educators, researchers, and policy makers have advocated student involvement for some time as an essential aspect of meaningful learning. In the past twenty years engineering educators have implemented several means of better engaging their undergraduate students, including active and cooperative learning, learning communities, service learning, cooperative education, inquiry and problem-based learning, and team projects. This paper focuses on classroom-based pedagogies of engagement, particularly cooperative and problem-based learning. It includes a brief history, theoretical roots, research support, summary of practices, and suggestions for redesigning engineering classes and programs to include more student engagement. The paper also lays out the research ahead for advancing pedagogies aimed at more fully enhancing students' involvement in their learning.

Keywords: cooperative learning, problem-based learning, student engagement

\section{INTRODUCTION TO THE PEDAGOGIES OF ENGAGEMENT}

Russ Edgerton introduced the term "pedagogies of engagement" in his 2001 Education White Paper [1], in which he reflected on the projects on higher education funded by the Pew Charitable Trusts. He wrote:

"Throughout the whole enterprise, the core issue, in my view, is the mode of teaching and learning that is practiced. Learning 'about' things does not enable students to acquire the abilities and understanding they will need for the twenty-first century. We need new pedagogies of engagement that will turn out the kinds of resourceful, engaged workers and citizens that America now requires."
Prior to Edgerton's paper, the widely distributed and influential publication called The Seven Principles for Good Practice in Undergraduate Education [2] stressed pedagogies of engagement in concept. Three of the principles speak directly to pedagogies of engagement, namely, that good practice encourages student-faculty contact, cooperation among students, and active learning.

More recently, the project titled The National Survey of Student Engagement (NSSE) [3] deepens our understanding of how students perceive classroom-based learning, in all its forms, as an element in the bigger issue of student engagement in their college education. The NSSE project conceives that student engagement is not just a single course in a student's academic career, but rather a pattern of his or her involvement in a variety of activities. As such, NSSE findings are a valuable assessment tool for colleges and universities to track how successful their academic practices are in engaging their student bodies. The NSSE project is grounded in the proposition that student engagement, the frequency with which students participate in activities that represent effective educational practice, is a meaningful proxy for collegiate quality and, therefore, by extension, quality of education. For example, the annual survey of freshmen and seniors asks students how often they have participated in, for example, projects that required integrating ideas or information from various sources, used e-mail to communicate with an instructor, asked questions in class or contributed to class discussions, received prompt feedback from faculty on their academic performance, participated in community-based projects, or tutored or taught other students. Student responses are organized around five benchmarks:

1. Level of academic challenge: Schools encourage achievement by setting high expectations and emphasizing importance of student effort.

2. Active and collaborative learning: Students learn more when intensely involved in educational process and are encouraged to apply their knowledge in many situations.

3. Student-faculty interaction: Students able to learn from experts and faculty serve as role models and mentors.

4. Enriching educational experiences: Learning opportunities inside and outside classroom (diversity, technology, collaboration, internships, community service, capstones) enhance learning.

5. Supportive campus environment: Students are motivated and satisfied at schools that actively promote learning and stimulate social interaction.

Astin's [4] large-scale correlational study of what matters in college (involving 27,064 students at 309 baccalaureate-granting institutions) found that two environmental factors were by far the most predictive of positive change in college students' academic development, personal development, and satisfaction. These two factorsinteraction among students and interaction between faculty and students - carried by far the largest weights and affected more general education outcomes than any other environmental variables 
studied, including the curriculum content factors. This result indicates that how students approach their general education and how the faculty actually deliver the curriculum is more important than the formal curriculum, that is, the content, collection, and sequence of courses.

The assessment study by Light $[5,6]$ of Harvard students strongly suggests that one of the crucial factors in the educational development of the undergraduate is the degree to which the student is actively engaged or involved in the undergraduate experience; this is consistent with Astin's work [4]. Astin and Light's research studies suggest that curricular planning efforts will reap much greater payoffs in terms of student outcomes if more emphasis is placed on pedagogy and other features of the delivery system, as well as on the broader interpersonal and institutional context in which learning takes place.

Pascarella and Terenzini's summary of twenty years of research on the impact college has on student development further supports the importance of student engagement:

\begin{abstract}
"Perhaps the strongest conclusion that can be made is the least surprising. Simply put, the greater the student's involvement or engagement in academic work or in the academic experience of college, the greater his or her level of knowledge acquisition and general cognitive development... If the level of involvement were totally determined by individual student motivation, interest, and ability, the above conclusion would be uninteresting as well as unsurprising. However, a substantial amount of evidence indicates that there are instructional and programmatic interventions that not only increase a student's active engagement in learning and academic work but also enhance knowledge acquisition and some dimensions of both cognitive and psychosocial change" [7].
\end{abstract}

Macgregor, Cooper, Smith, and Robinson [8] provided a synthesis of interviews conducted with forty-eight individuals teaching undergraduate classes across the United States who are infusing their large classes with small-group activities or are working explicitly to create student communities within large classes. The faculty who were interviewed are working with classes of more than 100 students, and some are teaching substantially larger classes, in the 350 to 600 student range. The faculty practicing small-group learning in large classes provided extensive empirical and theoretical rationale for their practices. Their reasons clustered in the following categories:

1. promoting cognitive elaboration;

2. enhancing critical thinking;

3. providing feedback;

4. promoting social and emotional development;

5. appreciating diversity; and

6. reducing student attrition.

Edgerton, in the aforementioned white paper, goes on to cite four strands of pedagogical reform that are moving in the same broad direction: problem-based learning, collaborative learning, service learning, and undergraduate research. This paper looks at a class of pedagogies of engagement, namely, those that are classroom-based. We focus particularly on cooperative learning and on problem-based learning.

In the next section we present definitions of the classroom-based pedagogies of engagement that are used in engineering undergraduate classrooms followed by a brief summary of their history (section III). Next we provide the theoretical foundations and research evidence for effectiveness (section IV), and offer model practices for implementation (section V). The paper concludes by presenting some unanswered questions about classroom-based pedagogies of engagement for engineering in particular and pedagogies in general.

\section{AN OVERVIEW}

"To teach is to engage students in learning." This quote, from Education for Judgment by Christensen et al. [9], captures the essence of the state of the art and practice of pedagogies of engagement. The thesis of this book, and this paper, is that engaging students in learning is principally the responsibility of the teacher, who becomes less an imparter of knowledge and more a designer and facilitator of learning experiences and opportunities. In other words, the real challenge in college teaching is not covering the material for the students; it's uncovering the material with the students.

Consider the most common model of the classroom-based teaching and learning process used in engineering education in the past fifty years (and maybe currently?). This model, illustrated in Figure 1(a), is a presentational model where, as one pundit quipped, "the information passes from the notes of the professor to the notes of the students without passing through the mind of either one."

An alternative to the "pour it in" model is the "keep it flowing around" model. This is shown in Figure 1(b) and illustrates that the information passes not only from teacher to student, but also from students to teacher and among the students. The model of teaching and learning represented in Figure 1(b) emphasizes that the simultaneous presence of interdependence and accountability are essential to learning, and their presence is at the heart of a student-engaged instructional approach.

The model of the teaching-learning process in Figure 1(b) is predicated on cooperation - working together to accomplish shared goals. Within cooperative activities individuals seek outcomes that are beneficial to themselves and beneficial to all other group members. Cooperative learning is the instructional use of small groups so that students work together to maximize their own and each others' learning $[10,11]$. Carefully structured cooperative learning involves people working in teams to accomplish a common goal, under conditions that involve both positive interdependence (all members must cooperate to complete the task) and individual and group accountability (each member individually as well as all members collectively accountable for the work of the group). Astin [12] reported that 14 percent of engineering faculty and 27 percent of all faculty said they used cooperative learning in most or all of their classes.

A common question is, "What is the difference between cooperative and collaborative learning?" Both pedagogies are aimed at "marshalling peer group influence to focus on intellectual and substantive concerns" [13]. Their primary difference is that cooperative learning requires carefully structured individual accountability, while collaborative does not. Numerous authors, such as Barkley, Cross, and Major [14], use the term collaborative learning to refer to predominantly cooperative learning research and practice. To try to minimize confusion, we will use the term cooperative learning throughout the current paper.

Problem-based learning (PBL) "is the learning that results from the process of working toward the understanding or resolution of a problem. The problem is encountered first in the learning process" [15]. Barrows [16] identified six core features of PBL: 


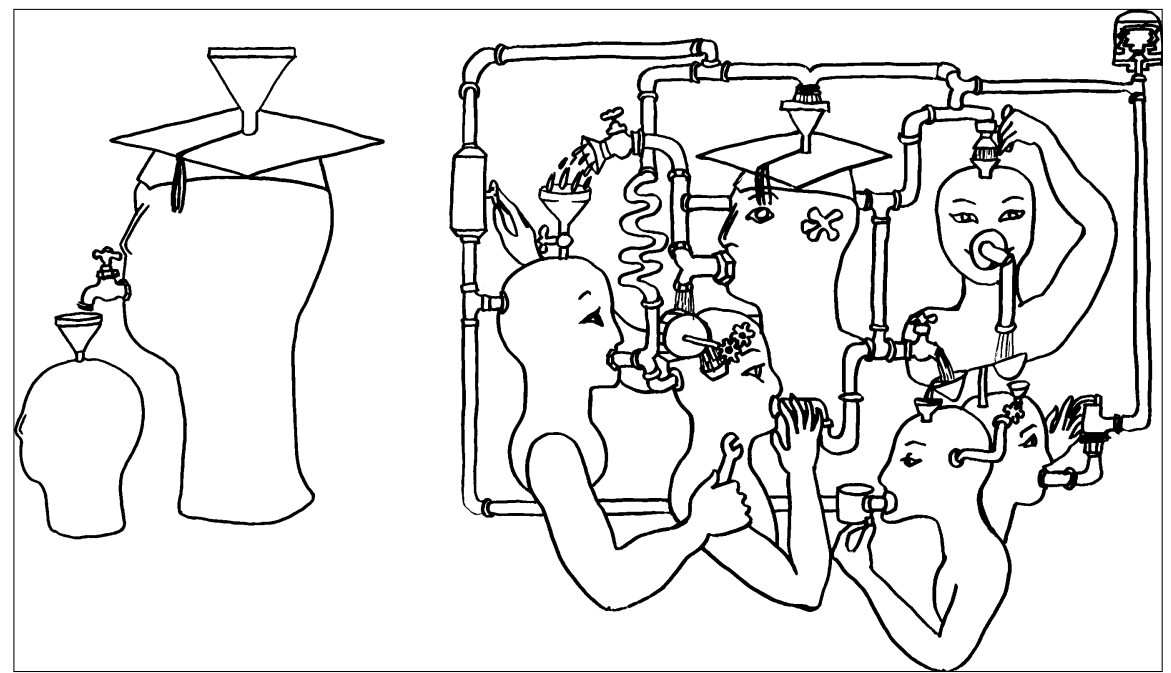

Figure 1. Two models of the classroom-based teaching learning process, as drawn by Lila Smith in about 1975. (a) "Pour it in" model; (b) "Keep it flowing" model.

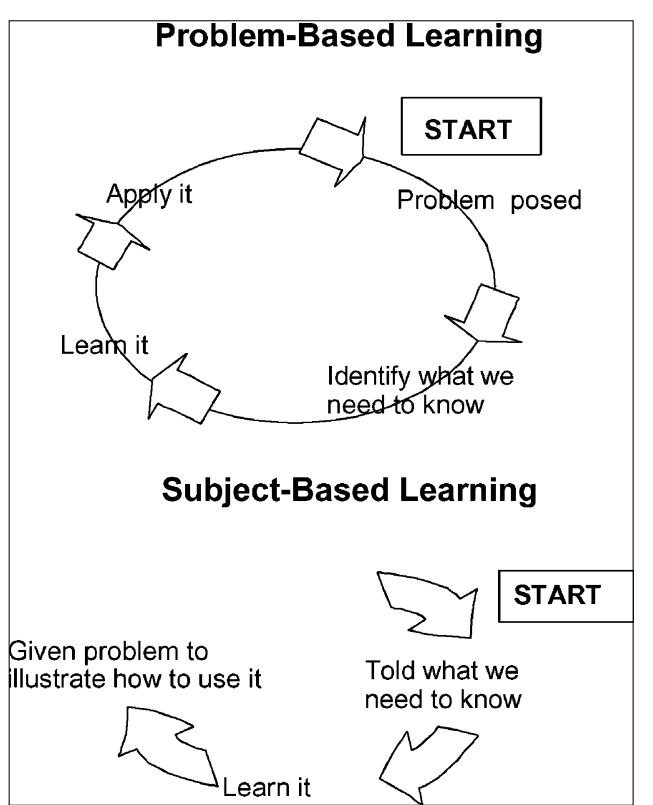

Figure 2. Problem-based learning contrasted with Subject based learning.

- Learning is student-centered.

- Learning occurs in small student groups.

- Teachers are facilitators or guides.

- Problems are the organizing focus and stimulus for learning.

- Problems are the vehicle for the development of clinical problem-solving skills.

- New information is acquired through self-directed learning.

The process of problem-based learning was illustrated by Woods [17], who contrasted it with subject-based learning (Figure 2). Problem-based learning is suitable for introductory sciences and engineering classes (as it is for medicine, where it is currently used) because it helps students develop skills and confidence for formulating problems they have never seen before. This is an important skill, since few science, mathematics, or engineering graduates are paid to formulate and solve problems that follow from the material presented in the chapter or have a single "right" answer that one can find at the end of a book. An example of a PBL problem, adapted from Adams' [18] "dangling from a wire problem," is to "estimate the diameter of the smallest steel wire that could suspend a typical American automobile."

The largest-scale implementation of PBL in the United States in undergraduate courses (including large introductory courses) is at the University of Delaware in Newark, Delaware, where it is used in many courses, including biology, biochemistry, chemistry, criminal justice, education, international relations, marine studies, mathematics, nutrition/dietetics, physics, political science, and exercise science $[19,20]$. The initial PBL work at the University of Delaware was supported by the National Science Foundation (NSF) and the Fund for Improvement of Post-Secondary Education (FIPSE); more than 25 percent of the faculty have participated in weeklong formal workshops on PBL. Allen and Duch recently described their implementation of PBL problems for introductory biology [21].

Woods at McMaster University has described the university's implementation of PBL in engineering [17]. In the chemical engineering program there, $\mathrm{PBL}$ is used as part of two courses: one topic or problem in a junior-level course; and five topics in a senior-level course [22]. PBL is used in a theme school program created at McMaster University and in a junior-level civil engineering course and a senior-level project course in geography. These are examples of the use of small group, self-directed PBL where tutorless groups of five to six students function effectively. The class sizes are in the range thirty to fifty, with one or two instructors. The students concurrently take conventional courses. Project-based learning, which focuses on a project and typically a deliverable in the form of a report or presentation, was emphasized in a recent publication on project/problem-based learning at Aalborg University in Denmark (all majors), Maastricht University in Maastricht, The Netherlands (which implemented the McMaster PBL model in medicine in

${ }^{1}$ Details of this example are available at www.ce.umn.edu/ smith. Many additional examples are available on the University of Delaware PBL Web site www.udel.edu/pbl. 
1974), and at universities in Australia. There is an excellent summary of these programs in PBL Insight [23]. A comparison of problembased and project-based learning is available in Mills and Treagust [24]. Project-based learning, which is often the basis for the senior design courses in undergraduate engineering curriculum in the United States, will not be further discussed in this paper; the reader is referred to the work of Dym et al. [25].

Lest the reader think that the model of the teaching-learning process illustrated in Figure 1(b) is a modern creation, consider the long and rich history of the practical use of pedagogies of engagement, especially classroom-based practices such as cooperative learning and problem-based learning. Thousands of years ago the Talmud stated that to understand the Talmud, one must have a learning partner. Confucius is typically credited with the Chinese proverb "Tell me and I forget; show me and I remember; involve me and I understand." (However, Edgerton [1] and others attribute the Lakota Sioux Indians). The Roman philosopher, Seneca, advocated cooperative learning through such statements as, "Qui Docet Discet" (when you teach, you learn twice). J. Amos Comenius (1592-1679) believed that students would benefit both by teaching and by being taught by other students. In the late 1700s, J. Lancaster and A. Bell made extensive use of cooperative learning groups in England and India, and the idea was brought to the America when a Lancastrian school was opened in New York City in 1806 [26].

One of the more successful advocates of cooperative learning in the United States was Colonel Francis Parker [27] in the late 1800s. Parker started several schools and hosted many visitors to his schools who in turn started or changed their own programs. In the last three decades of the nineteenth century, Colonel Parker advocated cooperative learning with enthusiasm, idealism, practicality, and an intense devotion to freedom, democracy, and individuality in the public schools. Following Parker, John Dewey promoted the use of cooperative learning groups as part of his famous project method in instruction [28]. John Dewey's ideal school involved

- a "thinking" curriculum aimed at deep understanding;

- cooperative learning within communities of learners;

- interdisciplinary and multidisciplinary curricula; and

- projects, portfolios, and other "alternative assessments" that challenged students to integrate ideas and demonstrate their capabilities.

In the late 1930s, however, public schools began to emphasize interpersonal competition and this view predominated for well over forty years [29].

In the mid-1960s Johnson and Johnson began training K-12 teachers and a few post-secondary teachers how to use cooperative learning at the University of Minnesota. The Cooperative Learning Center at the University of Minnesota resulted from their efforts to (a) synthesize existing knowledge concerning cooperative, competitive, and individualistic efforts, (b) formulate theoretical models concerning the nature of cooperation and its essential elements, (c) conduct a systematic program of research to test the theorizing, (d) translate the validated theory into a set of concrete strategies and procedures for using cooperative learning, and (e) build and maintain a network of schools implementing cooperative strategies and procedures throughout the world. From being relatively unknown and unused in the 1960s, cooperative learning is now an accepted and often the preferred instructional procedure at all levels of education throughout the world in every subject area and from preschool through graduate school and adult training programs [30].
Most of the work on developing and researching models of cooperative learning in the 1970s and 1980s focused on K-12 education. For example, in the early 1970s DeVries and Edwards [31] at Johns Hopkins University developed Teams-Games-Tournaments (TGT) and the Sharans in Israel developed the group investigation procedure for cooperative learning groups [32]. In the late 1970s Slavin and colleagues at Johns Hopkins University extended DeVries and Edwards' work by modifying TGT into Student-Teams-Achievement-Divisions (STAD) and modifying computer-assisted instruction into Team-Assisted Instruction (TAI) [32]. Concurrently, Kagan [34] developed cooperative learning structures that involved detailed procedures, such as numbered heads together. This was followed in the 1980s by Cohen developing a "complex instruction" version of cooperative learning $[35,36]$ and Dansereau [37] developing a number of cooperative learning scripts.

The 1980s and 1990s brought an expansion of cooperative learning models into engineering. The concept of a cooperative learning group was introduced to the engineering education community at the 1981 IEEE/ASEE Frontiers in Education (FIE) conference in Rapid City, S.D. [38]. Goldstein also presented a paper on cooperative learning at this conference and Goldstein and Smith were subsequently invited to present a workshop (probably the first) on cooperative learning at the 1982 FIE conference. Also, in 1981 the first in a series of papers on cooperative learning was published in Engineering Education, "Structuring learning goals to meet the goals of engineering education" [10]. In the mid-1990s the Foundation Coalition embraced the cooperative learning approach, produced several one-page summaries of concepts, and developed an extensive Web site on Active/Cooperative Learning: Best Practices in Engineering Education. ${ }^{2}$

More recently, Millis and Cottell [39] adapted Kagan's cooperative learning structures for higher education faculty, and Johnson, Johnson, and Smith began adapting the conceptual cooperative learning model to higher education [40-42].

\section{THEORY AND RESEARCH EVIDENCE}

The underling precept of cooperative and problem-based learning is interdependence. The term interdependence was introduced by Coleridge in 1822 and is defined, according to the Oxford English Dictionary, as "The fact or condition of depending each upon the other; mutual dependence." Many of the early references to the term, e.g., by Coleridge, Huxley, Spencer, were biology related. Spencer introduced the "conception of [society] as having a natural structure in which all its institutions, governmental, religious, industrial, commercial, etc., etc., are inter-dependently bound" ( $O x-$ ford English Dictionary)

Research on cooperative learning has been guided primarily by social interdependence theory. The theory was conceived of in the early 1900s, when one of the founders of the Gestalt School of Psychology, Kafka, proposed that groups were dynamic wholes in which interdependence among members could vary. One of his colleagues, Lewin [43], refined Kafka's notions in the 1920s and 1930s while stating that (a) the essence of a group is the interdependence

${ }^{2}$ See http://clte.asu.edu/active. 
among members (created by common goals) that results in the group's being a "dynamic whole" so that a change in the state of any member or subgroup changes the state of all other member or subgroup and (b) an intrinsic state of tension within group members motivates movement toward the accomplishments of the desired common goals. One of Lewin's graduate students, Deutsch, formulated the theory of cooperation and competition in the late 1940s $[44,45]$. One of Deutsch's graduate students, D. Johnson (collaborating with R. Johnson), extended Deutsch's work into classroom practices [46-48].

The social interdependence perspective assumes that the way social interdependence is structured determines how individuals interact, which in turn determines outcomes. Positive interdependence (cooperation) results in promotive interaction as individuals encourage and facilitate each other's efforts to learn. Negative interdependence (competition) typically results in oppositional interaction as individuals discourage and obstruct each other's efforts to achieve. In the absence of interdependence (individualistic efforts), there is no interaction as individuals work independently without any interchange with each other [44].

Extensive research has been conducted on cooperative learning-defined in section II as the instructional use of small groups so that students work together to maximize their own and each others' learning. From 1897 to 1989 nearly 600 experimental and more than 100 correlational studies were conducted comparing the effectiveness of cooperative, competitive, and individualistic efforts in promoting learning. Before 1970, almost all the reported studies were conducted in college classrooms and laboratories using college students as participants. The U.S. experimental research on cooperative learning has its roots in Deutsch's work in the late 1940s in a study at MIT [49]. Between 1970 and 1990 the majority of the studies were conducted in K-12 settings; however, in the 1990s, the interest in investigating the use of cooperative learning at the college level was rekindled.

Current meta-analysis work at the Cooperative Learning Center at the University of Minnesota identified 754 studies that compare the effectiveness of students working cooperatively, competitively, and individualistically from 1897 to the present. Eighty five percent were conducted since 1970; 43.5 percent had randomly assigned subjects and 18.8 percent had randomly assigned groups; 41.4 percent of the subjects were nineteen or older; 76.7 percent were published in a journal; 31 percent were laboratory studies and 65 percent were field studies [30]. These studies and others yet to be coded will be analyzed in the coming months.

The next two sections summarize the research on cooperative learning and problem-based learning at the post-secondary level, that is, the studies of higher education and adult populations.

\section{A. Cooperative Learning Research}

Approximately 305 studies were located at the Cooperative Learning Center and were used to compare the relative efficacy of cooperative, competitive, and individualistic learning in college and adult settings, as reported in $[41,42]$. The first of these studies was conducted in 1924; 68 percent of the studies have been conducted since 1970 . Sixty percent randomly assigned subjects to conditions, 49 percent consisted of only one session, and 82 percent were published in journals. These 305 studies form the research summarized below.

The multiple outcomes can be classified into three major categories: academic success, quality of relationships, and psychological adjustment to college life. In addition, there are a number of studies on students' attitudes toward the college experience.

1) Academic Success: One of the most important goals for engineering educators is that students succeed academically. Academic success is, above all, the college's aim and the student's aim. Between 1924 and 1997, more than168 rigorous research studies were conducted comparing the relative efficacy of cooperative, competitive, and individualistic learning on the achievement of individuals eighteen and older. This represents the subset of the 305 studies that focus on individual student acheivement. Other studies focused on students' attitudes, persistence (or retention), and other dependent measures. These studies indicate that cooperative learning promotes higher individual achievement than do competitive approaches or individualistic ones. The effect sizes, which indicate the magnitude of significance, were 0.49 and 0.53 for competitive and individualistic approaches, respectively. Effect sizes of this magnitude indicate significant, substantial increases in achievement. They can be interpreted as saying, for example, that college students who would score at the fiftieth percentile level on an individual exam when learning competitively will score in the sixty-ninth percentile when learning cooperatively; students who would score at the fiftythird percentile level when learning individualistically will score in the seventieth percentile when learning cooperatively [41]. For a briefing on the meta-analysis procedure see [49].

The relevant measures here include knowledge acquisition, retention, accuracy, creativity in problem solving, and higher-level reasoning. The results hold for verbal tasks (such as reading, writing, and oral presentations), mathematical tasks, and procedural tasks (such as laboratory exercises). There are also other subsets of the 305 studies showing significant advantages for cooperative learning in promoting meta-cognitive thought, willingness to take on difficult tasks, persistence (despite difficulties) in working toward goal accomplishment, intrinsic motivation, transfer of learning from one situation to another, and greater time spent on task.

The findings outlined above are consistent with results from a recent meta-analysis focused on college level-one science, mathematics, engineering, and technology (SMET) courses. Springer, Stanne, and Donovan's [49] study of small-group (predominantly cooperative) learning in SMET courses identified 383 reports from 1980 or later, thirty-nine of which met the rigorous inclusion criteria for meta-analysis. Of the thirty-nine studies analyzed, thirtyseven (94.9 percent) presented data on achievement, nine (23.1 percent) on persistence or retention, and eleven (28.2 percent) on attitudes. The main effect of small-group learning among undergraduates majoring in SMET disciplines was significant and positive, with mean effect sizes for achievement, persistence, and attitudes of $0.51,0.46$, and 0.55 , respectively.

Recent synthesis publications include Bowen's [50] summary of research on cooperative learning effects on chemistry and Prince's [51] summary of research on active and cooperative learning in engineering.

Research that has had a significant influence on the instructional practices of engineering faculty is Hake's [52] comparison of students' scores on the physics Force Concept Inventory (FCI), a measure of students' conceptual understanding of mechanics, in traditional lecture courses and interactive engagement courses. The results shown for high school (HS), college (COLL), and university (UNIV) students in Figure 3 show that student-student interaction during class time is associated with a greater percent gain on the 


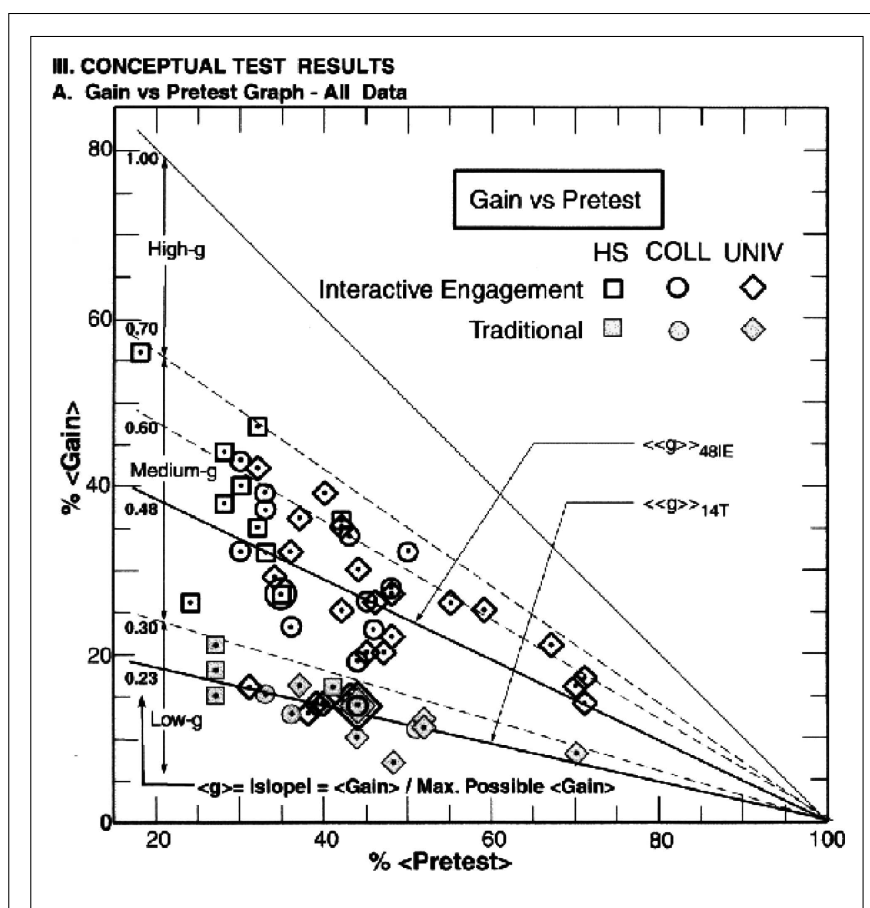

Figure 3. Plot of class average pre-test and post-test FCI scores using a variety of instructional methods [52].

FCI. Further study of the figure shows that even the best lectures achieve student gains that are at the low end of student gains in interactive engagement classes.

Redish [53] provides the following conjectures based on Hake's research:

- In the traditional (low-interaction lecture-based) environment, what the lecturer does can have a big impact on the class's conceptual gains.

- In the moderate active-engagement classes (one modified small-class group-learning hour per week), much of the conceptual learning relevant to FCI gains was occurring in the modified class.

- Full active-engagement classes can produce substantially better FCI gains, even in early implementation.

Cooperative learning researchers and practitioners have shown that positive peer relationships are essential to success in college. Isolation and alienation are the best predictors of failure. Two major reasons for dropping out of college are failure to establish a social network of friends and classmates and failure to become academically involved in classes [54]. Working together with fellow students, solving problems together, and talking through material together have other benefits as well [55]: "Student participation, teacher encouragement, and student-student interaction positively relate to improved critical thinking. These three activities confirm other research and theory stressing the importance of active practice, motivation, and feedback in thinking skills as well as other skills. This confirms that discussions are superior to lectures in improving thinking and problem solving."

2) Quality of Relationships: Tom Boyle of British Telecom calls this the age of interdependence; he speaks of the importance of people's network quotient, or NQ- their capacity to form connections (relationships) with one another, which, Boyle argues, is now more important than IQ the measure of individual intelligence [56].
Many researchers have investigated the quality of the relationships among students and between students and faculty. The metaanalysis of the 305 studies mentioned above found that cooperative effort promotes greater liking among students than does competing with others (effect size $=0.68$ ) or working on one's own (effect size $=$ 0.55); this finding holds even among students from different ethnic, cultural, language, social class, ability, and gender groups. The relevant studies included measures of interpersonal attraction, esprit de corps, cohesiveness, and trust. College students learning cooperatively perceive greater social support (both academically and personally) from peers and instructors than do students working competitively (effect size $=0.60)$ or individualistically (effect size $=0.51$ ).

The positive interpersonal relationships promoted by cooperative learning are crucial to today's learning communities. They increase the quality of social adjustment to college life, add social goals for continued attendance, reduce uncertainty about attending college, increase integration into college life, and reduce congruencies between students' interests and college curricula and in students' sense of belonging in college

3) Psychological Adjustment: Attending college, especially engineering school, requires considerable personal adjustment for many students. In reviewing the research, it found cooperativeness to be highly correlated with a wide variety of indices of psychological health; individualistic attitudes to be related to a wide variety of indices of psychological pathology; and competitiveness to be related to a complex mixture of indices of health and pathology. One important aspect of psychological health is self-esteem. The metaanalysis results indicate that cooperation tends to promote higher self-esteem than competitive (effect size $=0.47$ ) or individualistic (effect size $=0.29$ ) efforts. Members of cooperative groups also become more socially skilled than do students working competitively or individualistically.

4) Attitudes Toward the College Experience: The recent work of NSSE provides detailed information on student engagement. Selected findings from the 2003 NSSE Annual Report [3] that speak directly to practices in engineering schools include the following:

- Business and engineering majors are well below other fields in prompt feedback from faculty and the frequency of participation in integrative activities.

- Engineering students experience more academic challenge and active and collaborative learning than many other fields

- Engineering students have low levels of student-faculty interaction and supportive campus environment.

- Engineering students spend less time preparing for class than professors expect.

A number of studies show that cooperative learning promotes more positive attitudes toward learning, the subject area, and the college than do competitive or individualistic learning [41]. Further, numerous social psychological theories predict that students' values, attitudes, and behavioral patterns are most effective when developed and changed in cooperative groups.

The research on cooperative learning is extensive and compelling. Based on this research record, with its theoretical foundation, the confidence that college instructors have in the effectiveness of cooperative-learning procedures should be elevated. Furthermore, the research on cooperative learning has a validity and broad applicability rarely found in the educational literature. It has been conducted over eight decades by numerous researchers with markedly different orientations working in a variety of different 
colleges and countries. Research participants have varied with respect to economic class, age, sex, nationality, and cultural background. The researchers have employed a wide variety of tasks, subject areas, methods of structuring cooperative learning, and methods of measuring dependent variables, and methodologies. The volume and diversity of the research is almost unparalleled in educational research.

\section{B. Problem-Based Learning Research}

Problem-based learning is undergoing a renaissance in professional education, including engineering education [57], as well as research on PBL. PBL is not a new idea; it had its beginnings in 1968 in the M.D. program at McMaster University in Hamilton, Ontario, Canada. McMaster graduated its first PBL class in 1972. At about the same time the College of Human Medicine at Michigan State University implemented a problem-based program [58]. Problem-based learning expanded to other disciplines besides medicine at the University of Maastricht (which implemented the McMaster PBL model in medicine in 1974) and to all majors at Aalborg University.

Dochy, Segers, Van den Bossche, and Gijbels [59] provided an excellent and recent meta-analysis of PBL research, predominantly in medicine. They selected forty-three studies according to the following inclusion criteria (page 536):

1. The work had to be empirical. Although non-empirical literature and literature reviews were selected as sources of relevant research, this literature was not included in the analysis.

2. The characteristics of the learning environment had to fit the previously described core model of PBL [16].

3. The dependent variables used in the study had to be an operationalization of the knowledge and/or skills (i.e., knowledge application) of the students.

4. The subjects of study had to be students in tertiary education.

5. To maximize ecological validity, the study had to be conducted in a real-life classroom or programmatic setting rather than under more controlled laboratory conditions.

This meta-analysis considered the influence of PBL on the acquisition of knowledge and the skills to apply knowledge. The results suggest that students in PBL are better at applying their knowledge (skills), with both a statistically significant vote count and combined effect size (0.46). Also noteworthy is that research on the efficacy of $\mathrm{PBL}$ is beginning to extend to non-medical fields [60].

Prince provides an excellent summary of the PBL research, including landmark work by Albanese and Mitchell [61] and Vernon and Blake [62], in Academic Medicine. He noted that the results are mixed for medical school students and that "while PBL has been used in undergraduate engineering programs there is very little data available for its effectiveness with this population of students" [51, p. 228]. It is important to note that PBL, as studied in medical education, typically involves seven to ten students with a designated tutor, whereas the model of PBL in engineering usually involves groups of three to four, often using formal cooperative learning models, typically without a tutor.

\section{CLASSROOM IMPLEMENTATION}

Of the three key aspects of cooperative learning and problembased learning — theory, research, and practice - the practice piece

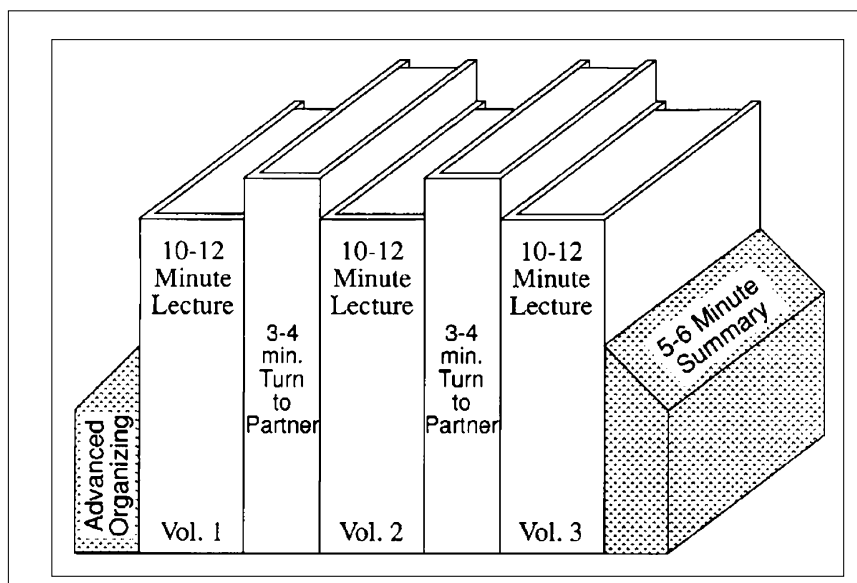

Figure 4. Bookends on a class session.

is the least developed and probably the most difficult. The classroom practices involved with cooperative learning and problem-based learning are complex to both design and implement, as well as to manage during the term. The NSF Foundation Coalition has actively focused on implementing active and cooperative learning for several years, including developing print materials, an extensive Web site, and a CD-ROM to support implementation. ${ }^{3}$ In spite of these implementation efforts and many others, cooperative learning and problem-based learning are not widely practiced in engineering classrooms. Part of the reason may be not only the difficulty of designing, implementing, and managing such a program, but also that most faculty did not experience any form of cooperative or problembased learning during their undergraduate (or graduate) education.

We remain hopeful, however, that the use of these pedagogies will continue to expand, not only because they are they effective, but also because there are many ways to implement them in engineering. In this section we highlight some well-developed and honed practices. Informal cooperative learning groups (often referred to as active learning), formal cooperative learning groups, and cooperative base groups are the most commonly implemented by engineering faculty. Each provides opportunities for students to be intellectually active and personally interactive both in and outside the classroom. Informal cooperative learning is commonly used in predominately lecture classes and is described only briefly. Formal cooperative learning can be used in content intensive classes where the mastery of conceptual or procedural material is essential; however, many faculty find it easier to start in recitation or laboratory sections or design project courses. Base groups are long-term cooperative learning groups whose principal responsibility is to provide support and encouragement for all their members; that is, to ensure that each member gets the help he or she needs to be successful in the course and in college.

\section{A. Implementing Informal Cooperative (Active) Learning}

Informal cooperative learning consists of having students work together to achieve a joint learning goal in temporary, ad-hoc groups that last from a few minutes to one class period [41]. Informal cooperative learning groups also ensure that misconceptions, incorrect understanding, and gaps in understanding are identified and corrected, and that learning experiences are personalized. In one instance of informal cooperative learning students are asked every ten to fifteen minutes to discuss what they are learning (see Figure 4).

\footnotetext{
${ }^{3}$ See http://clte.asu.edu/active.
} 
Breaking up lectures with short cooperative processing times results in slightly less lecture time, but re-engages the students. During lecturing and direct teaching, the instructor ensures that students do the intellectual work of organizing material, explaining it, summarizing it, and integrating it into existing conceptual networks. Common informal cooperative learning techniques include "focused discussions" before and after the lecture (bookends) and interspersing turn-to-your-partner discussions throughout the lecture. Although three to four minute turn-to-your-partner discussions are illustrated in Figure 4, many faculty provide one to two minutes, and some can be as short as thirty seconds.

As faculty gain familiarity with real-time assessment and informal cooperative learning, they often modify the format. For example, if most students choose the correct answer to a concept question, the instructor might ask students to reflect on the underlying rationale for their answer and to turn to their neighbor to discuss it. If most students choose an incorrect answer to a concept question, the instructor might try to explain it again, perhaps in a different way. If the answers to the concept question are a mixture of correct and incorrect, the instructor might ask students to turn to their neighbor, compare answers, and see if they can reach agreement on an answer.

Many examples of informal cooperative learning in practice are available. Mazur [63] describes the interactive aspects of a ninetyminute lecture on Newton's laws in Chapter 5 of his book Peer Instruction. Darmofal has written about his use of informal cooperative learning and concept tests in aeronautical engineering [64], and similarly Martin and colleagues have been actively experimenting with information cooperative learning and concept tests in fluid mechanics [65]. Further details of informal cooperative learning are available in numerous references, including Mazur [63], Landis, Ellis, Lisensky, Lorenz, Meeker, and Wamser [66], Novak, Patterson, Garvin, and Wolfgang [67], Michael and Modell [68], Felder and Brent [69], and Johnson, Johnson, and Smith [41].
Informal cooperative learning ensures that students are actively involved in understanding what they are learning. It also provides time for instructors to gather their wits, reorganize notes, take a break, and move around the class listening to what students are saying. Listening to student discussions can give instructors direction and insight into how well students understand the concepts and material being taught.

The importance of faculty engaging students in introductory courses, using procedures such as those summarized above, is stressed by Seymour's research: "The greatest single challenge to SMET pedagogical reform remains the problem of whether and how large classes can be infused with more active and interactive learning methods" [70].

\section{B. Implementing Formal Cooperative Learning Groups}

Formal cooperative learning groups are more structured than informal cooperative learning groups, are given more complex tasks, and typically stay together longer. Well-structured formal cooperative learning groups are differentiated from poorly structured ones on the basis of the characteristics presented in Table 1 . From these characteristics we can distill five essential elements to successful implementation of formal cooperative learning groups: positive interdependence, faceto-face promotive interaction, individual accountability/personal responsibility, teamwork skills, and group processing.

1) Positive Interdependence: The heart of cooperative learning is positive interdependence. Students must believe they are linked with others in a way that one cannot succeed unless the other members of the group succeed and vice versa. In other words, students must perceive that they sink or swim together. In formal cooperative learning groups, positive interdependence may by structured by asking group members to (1) agree on an answer for the group (group product-goal interdependence), (2) make sure each member can explain the groups' answer (learning goal interdependence), and (3) fulfill assigned role

\begin{tabular}{|l|l|}
\hline \multicolumn{1}{c|}{ Less Structured (Traditional) } & \multicolumn{1}{c|}{ More Structured (Cooperative) } \\
\hline $\begin{array}{l}\text { Low interdependence. Members take } \\
\text { responsibility only for themselves. Focus is } \\
\text { typically on a single product (report or } \\
\text { presentation). }\end{array}$ & $\begin{array}{l}\text { High positive interdependence. Members are } \\
\text { responsible for own and each other's learning. } \\
\text { Focus is on joint performance. }\end{array}$ \\
$\begin{array}{l}\text { Individual accountability only, usually } \\
\text { through exams and quizzes. }\end{array}$ & $\begin{array}{l}\text { Both group and individual accountability. } \\
\text { Members hold self and others accountable for } \\
\text { high quality work. }\end{array}$ \\
\hline $\begin{array}{l}\text { Little or no attention to group formation } \\
\text { (students often select members). Groups } \\
\text { typically large (4-8 members). }\end{array}$ & $\begin{array}{l}\text { Deliberately formed groups (random, } \\
\text { distribute knowledge/experience, interest). } \\
\text { Groups are small (2-4 members). }\end{array}$ \\
\hline $\begin{array}{l}\text { Assignments are discussed with little } \\
\text { commitment to each other's learning. }\end{array}$ & $\begin{array}{l}\text { Members promote each other's success, doing } \\
\text { real work together, helping and supporting } \\
\text { each other's efforts to learn. }\end{array}$ \\
\hline $\begin{array}{l}\text { Teamwork skills are ignored. Leader is } \\
\text { appointed to direct members' participation. }\end{array}$ & $\begin{array}{l}\text { Teamwork skills are emphasized. Members } \\
\text { are taught and expected to use collaborative } \\
\text { skills. Leadership role shared (by rotating for } \\
\text { example) among all members }\end{array}$ \\
\hline $\begin{array}{l}\text { No group processing of the quality of its } \\
\text { work. Individual accomplishments are } \\
\text { rewarded. }\end{array}$ & $\begin{array}{l}\text { Group processes quality of work and how } \\
\text { effectively members are working together. } \\
\text { Continuous improvement is emphasized. }\end{array}$ \\
\hline
\end{tabular}

Table 1. Comparison oflearning groups. 
responsibilities (role interdependence). Other ways of structuring positive interdependence include having common rewards such as a shared grade (reward interdependence), shared resources (resource interdependence), or a division of labor (task interdependence).

2) Face-to-Face Promotive Interaction: Once a professor establishes positive interdependence, he or she must ensure that students interact to help each other accomplish the task and promote each other's success. Students are expected to explain orally to each other how to solve problems, discuss with each other the nature of the concepts and strategies being learned, teach their knowledge to classmates, explain to each other the connections between present and past learning, and help, encourage, and support each other's efforts to learn. Silent students are uninvolved students who are certainly not contributing to the learning of others and may not be contributing to their own learning.

3) Individual Accountability/Personal Responsibility: One purpose of cooperative learning groups is to make each member a stronger individual in his or her own right. Students learn together so they can subsequently perform better as individuals. To ensure that each member is strengthened, students are held individually accountable to do their share of the work. The performance of each individual student is assessed and the results given back to the individual and perhaps to the group. The group needs to know who needs more assistance in completing the assignment, and group members need to know they cannot hitchhike on the work of others. Common ways to structure individual accountability include giving individual exams, using self-and peer-assessment, and randomly calling on individual students to report on their group's efforts.

4) Teamwork Skills: Contributing to the success of a cooperative effort requires teamwork skills, including skills in leadership, decision making, trust building, communication, and conflict management. These skills have to be taught just as purposefully and precisely as academic skills. Many students have never worked cooperatively in learning situations and and therefore lack the needed teamwork skills to doing so effectively. Faculty often introduce and emphasize teamwork skills by assigning differentiated roles to each group member. For example, students learn about documenting group work by serving as the task recorder, developing strategy and monitoring how the group is working by serving as process recorder, providing direction to the group by serving as coordinator, and ensuring that everyone in the group understands and can explain by serving as the checker. Teamwork skills are being emphasized by employers and the ABET engineering criteria, and resources are becoming available to help students develop teamwork skills (Smith [71] and Johnson and Johnson [72], for example). See Shuman, et al. [73] in this issue for elaboration on professional skills.

5) Group Processing: Professors need to ensure that members of each cooperative learning group discuss how well they are achieving their goals and maintaining effective working relationships. Groups need to describe what member actions are helpful and unhelpful and make decisions about what to continue or change. Such processing enables learning groups to focus on group maintenance, facilitates the learning of collaborative skills, ensures that members receive feedback on their participation, and reminds students to practice collaborative skills consistently. Some of the keys to successful processing are allowing sufficient time for it to take place, making it specific rather than vague, maintaining student involvement in processing, reminding students to use their teamwork skills during processing, and ensuring that clear expectations as to the purpose of processing have been communicated. A common procedure for group processing is to ask each group to list at least three things the group did well and at least one thing that could be improved.

The five essential elements of a well-structured formal cooperative learning group presented above are nearly identical to those of high-performance teams in business and industry as identified by Katzenbach and Smith:

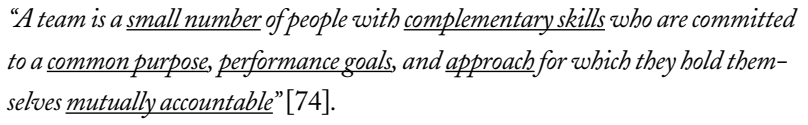

Many faculty who believe they are using cooperative learning are, in fact, missing its essence. There is a crucial difference between simply putting students in groups to learn and in structuring cooperation among students. Cooperation is not having students sit at the same table to talk with each other as they do their individual assignments. Cooperation is not assigning a report to a group of students where one student does all the work and the others put their names on the product as well. Cooperation is not having students do a task individually with instructions that the ones who finish first are to help the slower students. Cooperation is more than being physically near other students, discussing material with other students, helping other students, or sharing material among students, although each of these is important in cooperative learning.

Before choosing and implementing a formal cooperative learning strategy, several conditions should be evaluated to determine whether or not it is the best approach for the situation: sufficient time should be available for students to work in groups both inside and outside the classroom; the task should be complex enough to warrant a formal group; and the instructor's goals should include the development of skills that have been shown to be affected positively by cooperative learning, such as critical thinking, higher-level reasoning, and teamwork skills.

Detailed aspects of the instructor's role in structuring formal cooperative learning groups are described in [41] and include (1) specifying the objectives for the lesson, (2) making a number of instructional decisions, e.g., group size, method of assigning students to groups, (3) explaining the task and the positive interdependence, (4) monitoring students' learning and intervening within the groups to provide task assistance or to increase students' teamwork skills, and (5) evaluating students' learning and helping students process how well their group functioned.

For guidelines on designing formal cooperative learning lesson plans for structured controversy (using advocacy sub-groups in a cooperative context), the reader is referred to $[75,76]$. Details on implementing jigsaw (assigning material to be learned individually and then taught to a small cooperative learning group) can be found in $[77,78]$. Many additional examples of cooperative learning in practice are available. A full-text search of the Journal of Engineering Education, January 1993 through July 2004, for the phrase "cooperative learning" returned 132 hits. Three excellent examples of engineering applications are Felder and Brent, 2001 [79], Mourtos, 1997 [80], and Pimmel, 2001 [81].

\section{Implementing Cooperative Base Groups}

Cooperative base groups are long-term, heterogeneous cooperative learning groups with stable membership whose primary responsibility is to provide each student with the support, 
encouragement, and assistance needed to make academic progress. Base groups personalize the work required and the course learning experiences. They stay the same during the entire course and possibly longer. Members of base groups should exchange e-mail addresses and/or phone numbers and information about schedules, as they may wish to meet outside of class. When students have successes, insights, questions, or concerns they wish to discuss, they can contact other members of their base group. Base groups typically manage the daily paperwork of the course using group folders or Web-based discussion groups. Base groups are used by many engineering faculty in undergraduate courses and programs, in part because of their effectiveness and because they are easy to implement. They are also commonly used in professional school graduate programs. In this context they are usually referred to as cohort groups : five to six students who stay together during the duration of their graduate program.

\section{Implementing Problem-Based Learning}

Problem-based learning has been described in numerous references [17, 20, 59, 82-87]. Problem-based learning is a natural technique to use in engineering because it models the way most engineers work in practice. A typical format for problem-based cooperative learning is shown in Figure 5. The format illustrates the professor's role in a formal cooperative learning lesson and shows how the five essential elements of a well-structured cooperative lesson are incorporated $[41,88]$.

\section{V.THE WORK AHEAD}

This paper focused on illustrating how cooperative learning and problem-based learning can advance academic success, quality of

TASK: Complete the task or solve the problem.

INDIVIDUAL: Reflect and identify problem, formulate method, or estimate answer. Note strategy.

COOPERATIVE: One set of answers from the group, strive for agreement; make sure everyone is able to explain the strategies used to solve each problem.

EXPECTED CRITERIA FOR SUCCESS: Everyone must be able to explain the strategies used to solve each problem.

EVALUATION: Best answer within available resources or constraints.

INDIVIDUAL ACCOUNTABILITY: One member from any group may be randomly chosen to explain (a) the answer and (b) how to solve each problem.

EXPECTED BEHAVIORS: Active participating, checking, encouraging, and elaborating by all members.

INTERGROUP COOPERATION: Whenever it is helpful, check procedures, answers, and strategies with another group.

Figure 5. Problem-based cooperative learning. relationships, psychological adjustment, and attitudes toward the college experience. These particular pedagogies are examples of a broader category of pedagogies, commonly referred to as the pedagogies of engagement. Other examples include learning communities, service learning, and engineering co-ops. There is still much work to be done in advancing pedagogies of engagement: extending the theories that form their basis, conducting well-formulated experiments that elucidate the key components of successful deployment, and fostering and expanding the community of engineering faculty who use them. There are still many unanswered questions about pedagogies of engagement and their efficacy. For example,

1. Are some types of engineering classes (freshman or senior, lectures or project-based or labs, theoretical or applied) more or less conducive to any of the pedagogies of engagement?

2. Are there synergistic effects among the pedagogies of engagement?

3. What can be said about the effectiveness (in general and in engineering) of learning communities, service learning, cooperative education, and inductive methods besides problem-based learning, such as project-based learning (e.g., the Aalborg experience), inquiry-based learning, discovery learning, and just-in-time teaching? What studies of these methods should be carried out? Rigorous research on the effects of learning communities is just beginning to emerge. For example, a recent study by Zhao and Kuh [89] examined the relationship between participating in learning communities and student engagement for first-year and senior students at 365 four-year institutions. They found that "participating in a learning community is positively linked to engagement as well as student self-reported outcomes and overall satisfaction with college." Taylor, et al. caution us that "learning community assessment and research can and should probe more deeply into the nature of learning community interventions, and the nature of their impact on the learning of students, those who serve on teaching teams, and institutions" [90, p. iii].

4. What kind of "teacher effects" have been found for pedagogies of engagement? Are there teachers who cannot succeed with these methods? Are there teachers who are more successful with more traditional lecturing?

5. Can group-based methods have a negative effect on individual skills? How much of an effect, and what can be done to avoid it? Said another way, is there an optimum balance between group and individual work? If so, what does the balance depend on? (Level of course? Type of course? Prior background of the students?)

6. What are the differences in the benefits that result from properly implemented cooperative learning and properly implemented collaborative learning? Are there circumstances when collaborative would be preferable to cooperative?

7. How might emerging peer-assessment methods be integrated into pedagogies of engagement? Are there downsides to these assessment methods in supporting the intensions of cooperative learning and of collaborative learning? There is increasing interest in the engineering education community in implementing peer assessment in teambased learning settings. Some of this interest is motivated by faculty seeing peer assessment as a way to help students improve their cooperative skills, some by faculty seeing it as 
a way to reduce the number of "free-loaders" on a cooperative team, and some by faculty seeing it as a way to incorporate actual work contribution in awarding individual grades on a team project. In addition, the ABET engineering criterion that says engineering graduates will have demonstrated an "ability to function on multidisciplinary teams" is motivating some engineering programs to conceive of peer assessment as a way of demonstrating this ability. Little is known about how peer assessment affects the nature of the cooperative work itself; research is sorely needed to study this influence, as outlined in a recent NSF report authored by Sheppard et al. [91]. The work of Eschenbach [92], Cohen [93], and Schaeffer et al. [94] are examples of this type of research

8. Can the effects of the individual criteria that define cooperative learning be parsed out to determine which are the most and least important (or if you can delete any of the criteria and still get the benefits of cooperative learning)?

9. Most pedagogies of engagement implementations take place at the individual classroom level. Have there been any efforts to institutionalize pedagogies of engagement at the department or college level besides the project-based learning at Aalborg. How have they succeeded? What barriers to institutionalization exist and how can they be overcome? Can a NSSE-like methodology play a role in assessing the impact of these pedagogies?

10. Have the benefits of pedagogies of engagement that extend beyond graduation (e.g., to career success or to life-long learning) been demonstrated by research? What studies of this nature might be undertaken?

This is just a sampling of the many questions still to be addressed about pedagogies of engagement! Of course, a similar set of questions can be generated about other pedagogies, such as the traditional lecture, recitation sessions, laboratory learning, etc.

\section{Conclusion: ThINKING BIG AND THINKING DIFFERENTLY}

The research findings on pedagogies of engagement outlined in this paper, along with student engagement data available through NSSE, underscore former University of Michigan President (and professor of nuclear engineering) James Duderstadt's call for action:

"It could well be that faculty members of the twenty-first century college or university will find it necessary to set aside their roles as teachers and instead become designers of learning experiences, processes, and environments" [95, p. 7].

This is a call for us, as faculty teaching particular courses and as members of faculty teams who create and maintain engineering programs, to consider not only the content and topics that make up an engineering degree but also how students engage with these materials. It is also a call for us to explicitly consider how students engage in their college experience in both formal and informal ways. In moving forward we have numerous tools available to guide our thinking, such as Felder and Brent's [96] guidelines for course design considering the ABET engineering criteria, and a recent book by Fink [97], Creating Significant Learning Experiences: An Integrated Approach to Designing College Courses, that provides a comprehensive model to redesign courses we hope will have widespread applicability in engineering.

We might even take a "backward design" approach to redesigning our engineering programs, as suggested by Wiggins and McTighe
[98]. Their approach consists of three stages; the first stage consists of identifying desired results, and stages 2 and 3 involve determining acceptable evidence and planning instruction, respectively. In carrying out stage 1 , faculty consider to what extent an idea, topic, or process

- represents a big idea or has enduring value beyond the classroom;

- resides at the heart of the discipline;

- requires uncoverage; and

- offers potential for engaging students.

Colleagues of the authors who have applied these filters to their courses report that one-fourth to one-third of the material does not pass. Imagine what might happen if the same process were applied both at the course level and at the program level by faculty teams.

We know it is easy to slip into the traditional mode of lecture, but we all should be mindful of Wilbert McKeachie's [99] advice on lecturing: "I lecture only when I'm convinced it will do more good than harm." Classroom-based pedagogies of engagement, such as cooperative learning and problem-based learning, can help break the traditional lecture-dominant pattern. To maximize students' achievement, especially when they are studying conceptually complex and content-dense materials, instructors should not allow them to remain passive while they are learning. One way to get students more actively involved is to structure cooperative interaction into classes, getting them to teach course material to one another and to dig below superficial levels of understanding of the material being taught. It is vital for students to have peer support and to be active learners, not only so that more of them learn the material at a deeper level, but also so that they get to know their classmates and build a sense of community with them.

It is equally important that when seniors graduate they have developed skills in talking through material with peers, listening with real skill, knowing how to build trust in a working relationship, and providing leadership to group efforts. If faculty provide their students with training and practice in the social skills required to work cooperatively with others, they will have the satisfaction of knowing they have helped prepare students for a world where they will need to coordinate their efforts with others on the job, skillfully balance personal relationships, and be contributing members of their communities and society.

We close with the compelling case for the importance of cooperation and interdependence that W. Edwards Deming made in his book The New Economics for Industry, Government, Education:

"We have grown up in a climate of competition between people, teams, departments, divisions, pupils, schools, universities. We have been taught by economists that competition will solve our problems. Actually, competition, we see now, is destructive. It would be better if everyone would work together as a system, with the aim for everybody to win. What we need is cooperation and transformation to a new style of management. Competition leads to loss. People pulling in opposite directions on a rope only exhaust themselves: they go nowhere. What we need is cooperation. Every example of cooperation is one of benefit and gains to them that cooperate" [100].

\section{ACKNOWLEDGMENTS}

The authors are grateful to Rich Felder, their cognizant editor of this special issue of the Journal of Engineering Education, for his 
consistent support throughout the writing effort, to Jim Adams for providing an insightful review at a critical stage. In addition, the author teams wishes to acknowledge the many (anonymous) reviewers who helped us focus this paper, and Denise Curti who ensured that the final manuscript was properly formatted.

\section{REFERENCES}

[1] Edgerton, R., Education White Paper, 2001, http://www. perwundergradforum.org/wp1.html.

[2] Chickering, A.W., and Gamson, Z.F., "Seven Principles for Good Practice in Higher Education," American Association for Higher Education Bulletin, Vol. 39, 1987, pp. 3-7.

[3] National Survey of Student Engagement: The College Student Report-2003 Annual Report, Bloomington, IN: Center for Postsecondary Research, Indiana University, 2003.

[4] Astin, A., What Matters in College? Four Critical Years Revisited, San Francisco, Cal.: Jossey-Bass, 1993.

[5] Light, R.J., The Harvard Assessment Seminars: Second Report, Cambridge, Mass.: Harvard University, 1992.

[6] Light, R.J., Making the Most of College, Cambridge, Mass.: Harvard University Press, 2001.

[7] Pascarella, E.T., and Terenzini, P.T., How College Affects Students: Finding and Insights from Twenty Years of Research, San Francisco, Cal.: Jossey-Bass, 1991.

[8] MacGregor, J., Cooper, J., Smith., K., and Robinson, P., eds., "Strategies for Energizing Large Classes: From Small Groups to Learning Communities," New Directions for Teaching and Learning, 81. Jossey-Bass, 2000.

[9] Christensen, C.R., Garvin, D.A., and Sweet, A., Education for Judgment: The Artistry of Discussion Leadership, Cambridge, Mass.: Harvard Business School, 1991.

[10] Smith, K.A., Johnson, D.W., and Johnson, R.T., "Structuring Learning Goals to Meet the Goals of Engineering Education," Engineering Education, Vol. 72, No. 3, 1981, pp. 221-226.

[11] Johnson, D.W., Johnson, R.T., and Smith, K.A., Cooperative Learning: Increasing College Faculty Instructional Productivity, ASHEERIC Report on Higher Education, Washington, D.C.: The George Washington University, 1991.

[12] Astin, A.W., "Engineering Outcomes," Prism, Vol. 3, No. 1, 1993, pp. 27-30.

[13] Bruffee, K., Collaborative Learning: Higher Education, Interdependence, and the Authority of Knowledge, Baltimore, Md.: Johns Hopkins University Press, 1999.

[14] Barkley, E., Cross, K.P, and Major, C.H., Collaborative Learning Techniques: A Practical Guide to Promoting Learning in Groups, San Francisco, Cal.: Jossey Bass, 2004.

[15] Barrows, H.S., and Tamblyn, R.N., Problem-Based Learning: An Approach to Medical Education, New York, N.Y.: Springer, 1980.

[16] Barrows, H.S., "Problem-Based Learning in Medicine and Beyond: A Brief Overview, in Wilkerson, L. and Gijselaers, W.H., eds., New Directions for Teaching and Learning, No. 68, 1996, pp. 3-11, San Francisco, Cal.: Jossey-Bass Publishers.

[17] Woods, D.R., Problem-Based Learning: How to Gain the Most from PBL, Waterdown, Ontario: Donald R. Woods, 1994.

[18] Adams, J.L., Flying Buttresses, Entropy, and O-rings: The World of an Engineer, Cambridge, Mass.: Harvard University Press, 1991.

[19] Allen, D.E., Duch, B.J., and Groh, S.E., "The Power of Problem-Based Learning in Teaching Introductory Science Courses," in
Wilkerson, L. and Gijselaers, Bringing Problem-Based Learning to Higher Education: Theory and Practice, New Directions for Teaching and Learning 68, San Francisco, Cal.: Jossey-Bass, 1996.

[20] Duch, B.J., Groh, S.E., and Allen, D.E., The Power of ProblemBased Learning: A Practical "How To" for Teaching Undergraduate Courses in any Discipline, Stylus, 2001.

[21] Allen, D., and Duch, B., Thinking Toward Solutions: ProblemBased Activities for General Biology, Fort Worth, Tex.: Saunders, 1998.

[22] Woods, D.R., "Issues in Implementation in an Otherwise Conventional Programme," Ch. 12, pp. 122-129, in Boud, D. and Feletti, G., eds., The Challenges of Problem-based Learning," London: Kogan Page, 1991.

[23] PBL Insight Vol. 2, No. 1, http://www.samford.edu/ pubs/ pbl/pblv2is1.pdf.

[24] Mills, J.E. and Treagust, D.F., "Engineering Education-Is Problem-Based or Project-Based Learning the Answer?" Austraaslian Journal of Engineering Education, http://www.aaee.com.au/journal/ 2003/mills_treagust03.pdf.

[25] Dym, C., Agogino, A., Eris, O., Frey, D., and Leifer, L., "Engineering Design Thinking, Teaching, and Learning," Journal of Engineering Education, Vol. 94, No. 1, January 2005, pp. X-Y.

[26] Lancaster, J., Improvements in Education, Abridged. Containing a complete epitome, of the system of education, invented and practiced by the author, London: Printed and sold by J. Lancaster, 1808.

[27] Campbell, J., "The Children's Crusader: Colonel Francis W. Parker," Ph.D. Dissertation, Teachers College, Columbia University, 1965.

[28] Dewey, J., The School and Society, 2nd ed., Chicago, Ill: University of Chicago Press, 1924.

[29] Pepitone. E., Children in Cooperation and Competition, Lexington, Mass.: Lexington Books, 1980.

[30] Johnson, D.W., and Johnson, R.T., "Cooperative Learning and Social Psychology: The Interrelationship Among Theory, Research, and Practice," Symposium: Efforts to Bridge Social Psychology and Education, Harris Cooper, Chair, Society of Experimental Social Psychology, Annual Conference, Dallas, October 15-16, 2004.

[31] DeVries, D., and Edwards, K., "Learning Games and Student Teams: Their Effects on Classroom Processes," American Education Research Journal, Vol. 10, 1974, pp. 307-318.

[32] Sharan, S., and Sharan, Y., Small Group Teaching, Englewood Cliffs, N.J.: Educational Technology, 1976.

[33] Slavin, R., Leavey, M., and Madden, N., Team-Assisted Individualization: Mathematics Teacher's Manual, John Hopkins University: Center for Social Organization of Schools, 1982.

[34] Kagan, S., Cooperative Learning, San Juan Capistrano, Cal.: Resources for Teachers, 1991.

[35] Cohen, E., Designing Groupwork: Strategies for the Heterogeneous Classroom, New York, N.Y.: Teachers College Press, 1986.

[36] Cohen, E., "Restructuring the Classroom: Conditions for Productive Small Groups, Revierw of Educational Research, Vol. 6, 1994, pp. 1-35.

[37] Dansereau, D.F., and Johnson, D.W., Cooperative Learning, Ch. 5, pp. 83-111; references pp. 319-327). in Druckman, D. and Bjork, R.A., eds., Learning, Remembering, Believing: Enhancing Human Performance, Washington, D.C.: National Academy Press, 1994.

[38] Smith, K.A., Johnson, D.W., and Johnson, R.T., "The Use of Cooperative Learning Groups in Engineering Education, Proceedings, Eleventh Annual Frontiers in Education Conference, Washington, D.C.: IEEE/ASEE, 1981, pp. 26-32.

[39] Millis, B.J., and Cottell, P.G., Cooperative Learning for Higher Education Faculty, Phoenix, Ariz.: American Council on Education and the Oryx Press, 1998. 
[40] Johnson, David W., Johnson, Roger T., and Smith, Karl A., Active Learning: Cooperation in the College Classroom. Edina, MN: Interaction Book Company, 1991.

[41] Johnson, D.W., Johnson, D.T., and Smith, K.A., Active Learning: Cooperation in the College Classroom, 2nd ed., Edina, Minn: Interaction Book Company, 1998.

[42] Johnson, D.W., Johnson, R.T., and Smith, K.A., "Cooperative Learning Returns to College: What Evidence Is There that it Works? Change, Vol. 30, No. 4, 1998, pp. 26-35.

[43] Lewin, K., A Dynamic Theory of Personality, New York, N.Y.: McGraw-Hill, 1935.

[44] Deutsch, M., "A Theory of Cooperation and Competition," Human Relations, Vol. 2, 1949, pp. 129-152.

[45] Deutsch, M., "Cooperation and Trust: Some Theoretical Notes," in Jones, M.R., ed., Nebraska Symposium on Motivation, 1962, pp. 275-319, Lincoln, NE: University of Nebraska Press.

[46] Johnson, D.W., The Social Psychology of Education, New York, N.Y.: Holt, Rinehart \&Winston, 1970.

[47] Johnson, D.W., and Johnson, R.T., "Instructional Goal Structure: Cooperative, Competitive, or Individualistic," Review of Educational Research, Vol. 44, 1974, pp. 213-240.

[48] Johnson, D.W. and Johnson, R.T., Cooperation and Competition: Theory and Research, Edina, Minn: Interaction Book Company, 1989.

[49] Springer, L., Stanne, M.E., and Donovan, S. S., "Effect of Small Group Learning on Undergraduates in Science, Mathematics, Engineering and Technology: A Meta-Analysis," Review of Educational Research, Vol. 69, 1, 1999, pp.21-51.

[50] Bowen, C.W., "A Quantitative Literature Review of Cooperative Learning Effects on High School and College Chemistry Achievement," Journal of Chemical Education, Vol. 77, 2000, p. 116.

[51] Prince, M., "Does Active Learning Work? A Review of the Research," Journal of Engineering Education, Vol. 93, No. 3, 2004, pp. 223-246.

[52] Hake, R., "Interactive-Engagement vs. Traditional Methods: A Six-Thousand Student Survey of Mechanics Test Data for Introductory Physics Courses," American Journal of Physics, Vol. 66, No. 1, 1998, pp. 64-74.

[53] Redish, E.F., Teaching Physics with the Physics Suite, New York, N.Y.: Wiley, 2003.

[54] Tinto, V., Leaving College: Rethinking the Causes and Cures of Student Attrition, 2nd ed., Chicago, Ill.: University of Chicago Press, 1994.

[55] McKeachie, W., Pintrich, P., Yi-Guang, L., and Smith, D., Teaching and Learning in the College Classroom: A Review of the Research Literature, Ann Arbor, Mich.: The Regents of the University of Michigan, 1986.

[56] Cohen, D., and Prusak, L., In Good Company: How Social Capital Makes Organizations Work, Cambridge, Mass.: Harvard Business School Press, 2001.

[57] Wilkerson, L., and Gijselaers, W.H., "Bringing Problem-Based Learning to Higher Education: Theory and Practice," Nerw Directions for Teaching and Learning, 68, San Francisco, Cal.: Jossey-Bass, 1996.

[58] Jones, J.W., Bieber, L.L., Echt, R., Scheifley, V., and Ways, P.O., "A Problem-Based Curriculum-Ten Years of Experience," in Schmidt, H.G. and DeVolder, M.L., eds., Tutorials in Problem-Based Learning, Assen/Maastricht, The Netherlands: Van Gorcum, 1984.

[59] Evensen, D.H., and Hmelo, C.E., Problem-Based Learning: $A R e-$ search Perspective on Learning Interactions, Mahwah, N.J.: Erlbaum, 2000.

[60] Dochy, F., Segers, M., Van den Bossche, P., and Gijbels, D., "Effects of Problem-Based Learning: A Meta-Analysis," Learning and Instruction, Vol. 13, 2003, pp. 533-568.
[61] Albanese, M.A., and Mitchell, S., "Problem-Based Learning: A Review of Literature on its outcomes and implementation Issues, Academic Medicine, Vol68, 1993, pp. 52-81.

[62] Vernon, D.T.A., and Blake, R. L., "Does Problem-Based Learning Work? A Meta-Analysis of Evaluative Research," Academic Medicine, Vol. 68, 1993, pp. 550-563.

[63] Mazur, E., Peer Instruction: A User's Manual, Upper Saddle River, N.J.: Prentice Hall, 1997.

[64] Darmofal, D., "Educating the Future: Impact of Pedagogical Reform in Aerodynamics," in Caughey, D.A. and Hafez, M.M., eds., Computing the Future IV: Frontiers of Computational Fluid Dynamics, SpringerVerlag, 2005.

[65] Martin, J., Mitchell, J., Newell, T., "Development of a Concept Inventory for Fluid Mechanics", FIE 2003 Conference Proceedings, Nov. 2003.

[66] Landis, C.R., Ellis, A.B., Lisensky, G.C., Lorenz, J.K., Meeker, K., and Wamser, C.C., Chemistry Concepts: A Pathway to Interactive Classrooms, Upper Saddle River, N.J.: Prentice Hall, 2001.

[67] Novak, G.M., Patterson, E.T., Garvin, A.D., and Christian, W., Just-In-Time Teaching: Blending Active Learning with Web Technology, Upper Saddle River, N.J.: Prentice Hall, 1999.

[68] Michael, J.A., and Modell, H.I., Active Learning in Secondary and College Science Classrooms A Working Model for Helping the Learner to Learn, Mahwah, N.J.: Lawrence Erlbaum, 2003.

[69] Felder, R.M., and Brent, R., "Learning by Doing," Chemical Engineering Education, Vol. 37, No. 4, 2003, pp. 282-283. Online at bttp://www.ncsu.edu/felder-public/Columns/Active.pdf.

[70] Seymour, E., "Tracking the Processes of Change in U.S. Undergraduate Education in Science, Mathematics, Engineering, and Technology" Science Education, Vol. 86, 2001, pp. 79-105.

[71] Smith, K.A., Teamwork and Project Management, New York, N.Y.: McGraw-Hill. BEST Series, 2004.

[72] Johnson, D.W., and Johnson, F., Joining Together: Group Theory and Group Skills, 7th ed., Boston, Mass.: Allyn \& Bacon, 2000.

[73] Shuman, L., Besterfield-Sacre, M., and McGourty, J., "The ABET "Professional Skills-Can they be Taught? Can they be Assessed?" Journal of Engineering Education, Vo. 94, No. 1, January 2005, pp. Y-Y.

[74] Katzenbach, J.R., and Smith, D.K., The Wisdom of Teams: Creating the High-Performance Organization, Cambridge, Mass.: Harvard Business School Press, 1993.

[75] Smith, K.A., "Structured Controversy," Engineering Education, Vol. 74, No. 5, 1984, pp. 306-309.

[76] Johnson, D.W., Johnson, R.T., and Smith, K.A., "Constructive Controversy: The Power of Intellectual Conflict," Change, Vol. 32, No. 1, 2000, pp. 28-37.

[77] Aronson, E., The Jigsaw Classroom, Beverly Hills, Cal.: Sage Publications, 1978.

[78] Smith, K.A., 'Cooperative Learning: Making 'Groupwork' work," in Bonwell, C. and Sutherlund, T., eds., Active learning: Lessons from practice and emerging issues. New Directions for Teaching and Learning 67, 1996, pp. 71-82, San Francisco: Jossey-Bass.

[79] Brent, R., "Effective Strategies for Cooperative Learning." Journal of Cooperation E Collaboration in College Teaching, Vol. 10, No. 2, 2001, pp. 69-75.

[80] Mourtos, N.J., "The Nuts and Bolts of Cooperative Learning in Engineering," Journal of Engineering Education, Vol. 86, No. 1, 1997, pp. 35-37.

[81] Pimmel, R., "Cooperative Learning Instructional Activities in a Capstone Design Course," Journal of Engineering Education, Vol. 90, No. 3, 2001, pp. 413-422. 
[82] Boud, D., and Feletti, G.E., The Challenge of Problem-Based learning, London: Kogan Paul, 1997.

[83] Bridges, E.M., and Hallinger, P., Implementing Problem Based Learning in Leadership Development, Eugene, Ore.: ERIC Clearinghouse on Educational Management, 1995.

[84] Knowlton, D., and Sharp, D., "Problem-Based Learning in the Information Age," New Directions for Teaching and Learning 95. San Francisco: Jossey-Bass, 2003.

[85] Smith, K.A., and Starfield, A.M., "Building Models to Solve Problems," pp. 254-264, in Clarke, J.H. and Biddle, A.W., eds., Teaching Critical Thinking: Reports from Across the Curriculum, Englewood Cliffs, N.J.: Prentice-Hall, 1993.

[86] Starfield, A.M., Smith, K.A., and Bleloch, A., How to Model It: Problem Solving for the Computer Age, 2nd ed., Edina, Minn.: Burgess Press, 1994.

[87] Savin-Baden, M., Facilitating Problem-Based Learning: Illuminating Perspectives. Berkshire, England: SRHE and Open University Press, 2003.

[88] Johnson, D.W., Johnson, R.T., and Smith, K.A., "Maximizing Instruction Through Cooperative Learning," pp. 24-29, ASEE Prism, Vol. 7, 6, 1998.

[89] Zhao, C.-M. and Kuh, G.D. "Adding Value: Learning Communities and Student Engagement,” Research in Higher Education, In Press.

[90] Taylor, K., Moore, W.S., MacGregor, J., and Lindblad, J., Learning Community Research and Assessment: What We Know Now, National Learning Communities Project Monograph Series. Olympia, Wash.: The Evergreen State College, Washington Center for Improving the Quality of Undergraduate Education, in cooperation with the American Association of Higher Education, 2003.

[91] Sheppard, S., Peer Assessment of Student Collaborative Processes in Undergraduate Engineering Education, Final Report to National Science Foundation, Award Number 0206820, NSF Program 7431 CCLIASA, Sheri Sheppard, Helen L. Chen, Evonne Schaeffer, Reinhold Steinbeck, Stanford Center for Innovations in Learning, June 2004.

[92] Eschenbach, E.A., and Mesmer, M.A., "Web Based Forms for Design Team Peer Evaluations," Proceedings, ASEE Annual Conference, 1998.

[93] Schaeffer, E., Nash, J., and Michalchik, V., Small Group Collaboration in the Large Lecture Setting: Challenges for Assessment, Paper presented at the Annual Meeting of the American Association of Higher Education Assessment Conference, Denver, Colo., June 2001.

[94] Cohen, E., "Restructuring the Classroom: Conditions for Productive Small Groups," Review of Educational Research, Vol. 6, 1994, pp. 1-35.

[95] Duderstadt, J.J., "Can Colleges and Universities Survive in the Information Age?" n Katz, R.N. and Associates, eds., Dancing With the Devil: Information Technology and the New Competition in Higher Education, San Francisco, Cal.: Jossey-Bass, 1999.

[96] Felder, R.M. and Brent, R., "Designing and Teaching Courses to Satisfy the ABET Engineering Criteria," Journal of Engineering Education, Vol. 92, No. 1, 2003, pp. 7-25.

[97] Fink, L.D., Creating Significant Learning Experiences: An Integrated Approach to Designing College Courses, San Francisco, Cal.: Jossey-Bass, 2002.

[98] Wiggins, G., and McTighe, J., Understanding by Design,. Alexandria, Va.: ASCD, 1998.

[99] McKeachie, W., "Teaching Thinking," in National Center for Research for the Improvement of Postsecondary Teaching and Learning Update, Vol. 1, No. 2, 1988.
[100] Deming, W.D., The New Economics for Industry, Government, Education, Cambridge, Mass: MIT Center for Advanced Engineering Study, 1993.

\section{AUTHOR's BIOGRAPHIES}

Karl A. Smith is Morse-Alumni Distinguished Teaching Professor and professor of civil engineering at the University of Minnesota. His research interests include the role of cooperation in learning and design; problem formulation, modeling, and knowledge engineering; and project and knowledge management and leadership. His bachelor's and master's degrees are in metallurgical engineering from Michigan Technological University and his $\mathrm{Ph} . \mathrm{D}$. is in educational psychology from the University of Minnesota. Karl has received numerous awards, including Distinguished Service Award, Educational Research and Methods Division, American Society for Engineering Education; Chester F. Carlson Award for Innovation in Engineering Education, American Society for Engineering Education; Outstanding Contributions to Cooperative Learning Award,; Cooperative Learning Special Interest Group, American Association for Higher Education; fellow, American Society for Engineering Education; Ronald J. Schmitz Award for outstanding continued service to engineering education through contributions to the Frontiers in Education Conference, ERM Division of ASEE and Education Society of IEEE. He is currently co-PI on two NSF-CTLs-Center for the Advancement of Engineering Education (CAEE) and National Center for Engineering and Technology Education (NCETE) and co-PI on a NSF-CCLI-ND-Rigorous Research in Engineering Education: Cultivating a Community of Practice. He serves on the National Advisory Boards for the NSF-CLT Center for the Integration of Research, Teaching and Learning; and the National Academy of Engineering's Center for the Advancement of Scholarship on Engineering Education. He is editor-in-chief of the $A n-$ nals of Research on Engineering Education. He is a visiting professor of engineering education at Purdue University for the 2004-2005 academic year. Address: Civil Engineering, University of Minnesota, 236 Civil Engineering, 500 Pillsbury Drive SE, Minneapolis, MN 55455, telephone: (612) 625-0305, FAX: (612) 626-7750, e-mail: ksmith@umn.edu, URL:http://www.ce.umn.edu/ smith

Sheri D. Sheppard, Ph.D., P.E., Senior Scholar, is the Carnegie Foundation for the Advancement of Teaching Senior Scholar principally responsible for the Preparations for the Professions Program (PPP) engineering study. In addition, she is an associate professor of mechanical engineering at Stanford University. Besides teaching both undergraduate and graduate design-related classes at Stanford University, she conducts research on weld fatigue and impact failures, fracture mechanics, and applied finite element analysis. Dr. Sheppard is co-principal investigator on a National Science Foundation (NSF) grant to form the Center for the Advancement of Engineering Education (CAEE), along with faculty at the University of Washington, Colorado School of Mines, and Howard University. In 1999 Sheri was named a fellow of the American Society of Mechanical Engineering (ASME) and the American Association for the Advancement of Science (AAAS), and in 2004 was awarded the ASEE Chester F. Carlson Award in recognition of distinguished accomplishments in engineering education. Before 
coming to Stanford University, she held several positions in the automotive industry, including senior research engineer at Ford Motor Company's Scientific Research Lab. She also worked as a design consultant, providing companies with structural analysis expertise. Dr. Sheppard's graduate work was done at the University of Michigan (1985).

David W. Johnson is a professor of educational psychology at the University of Minnesota where he holds the Emma M. Birkmaier Professorship in Educational Leadership. He is co-director of the Cooperative Learning Center. He received a master's and a doctoral degree from Columbia University. He is a past-editor of the American Educational Research Journal. He has published more than 350 research articles and book chapters and is the author of more than forty books (most co-authored with R. Johnson), including The Social Psychology of Education, Reaching Out: Interpersonal Effectiveness and Self-Actualization, Joining Together: Group Theory and Group Skills, and many others. Some of his national awards include the following. In 1972 he received a National Research Award In Personnel And Guidance from the American Personnel and Guidance Association and in 1981 he received the Gordon Allport Award for outstanding research on intergroup relationships from Division Nine of the American Psychological Association. The Emma M. Birkmaier Professorship in Educational Leadership (1994-1997) awarded by the College of Education, University of Minnesota. In 1996-1997 he was the Libra Endowed Chair, Visiting Professor, University of Maine at Presque Isle. For the past thirty-five years David has served as an organizational consultant to schools and businesses in such areas as management training, team building, ethnic relations, conflict resolution, interpersonal and group skills training, drug abuse prevention, and evaluating attitudinal/affective outcomes of educational and training programs. He is a recognized authority on experiential learning and currently provides training for clients in North America, Central America, Europe, Asia, the Middle East, and the Pacific Region.

Roger T. Johnson is a professor in the Department of Curriculum and Instruction with an emphasis in science education at the University of Minnesota. He holds an M.A. from Ball State University and an Ed.D from the University of California in Berkeley. His public school teaching experience includes teaching in kindergarten through eighth grade in self-contained classrooms, open schools, nongraded situations, cottage schools, and departmentalized (science) schools. Roger Johnson has been the recipient of several national awards, including the Research Award in Social Studies Education presented by the National Council for the Social Studies, the Helen Plants Award from the American Society for Engineering Education, the Gordon Allport Intergroup Relations Award from the Society for the Psychological Study of Social Issues (Division 9 of the American Psychological Association), the Alumni of the year award from Teachers College, Ball State University, and the Outstanding Contribution to Research and Practice in Cooperative Learning Award from the American Educational Research Association Special Interest Group on Cooperative Learning. He is the co-director of the Cooperative Learning Center, which conducts research and training nationally and internationally on changing the structure of classrooms and schools to a more cooperative environment. 